\title{
Faktor-Faktor yang Mempengaruhi Perilaku Auditor dalam Penghentian Prematur Atas Prosedur Audit
}

\author{
ASTIA PUTRIANA; NOVITA WENINGTYAS RESPATI*; CHAIRINA \\ Program Studi Akuntansi, Universitas Lambung Mangkurat, Jalan Brigjend H. Hasan Basri Kotak Pos 29 Banjarmasin, Kalimantan Selatan, 70123, \\ Telp +62 5113305116 Indonesia. \\ *Corresponding author, E_mail address:novifeunlam@yahoo.com
}

\begin{abstract}
The purpose of this research is to examine the effect of time pressure, audit risk, materiality, review procedure and quality control, need for achievement, and professional commitments on the auditor in premature termination on audit procedures. This reseach applies a mail survey as data collection method and convienece sampling as sample collection method. Research subjects are 106 auditor at the Supreme Audit Board of the Republic of Indonesia (BPK RI) Representative of South Kalimantan and Central Kalimantan. Empirical evidence finds that audit risk effect toward premature termination on the audit procedures. However, time pressure, materiality, review procedure and quality control, need for achievement and professional commitment does not effect toward premature termination on the audit procedures.
\end{abstract}

Keywords: Factors; Premature Sign Off; Audit procedures.

\section{ABSTRAK}

Tujuan dari penelitian ini adalah untuk menguji pengaruh tekanan waktu, risiko audit, materialitas, reviu prosedur dan kontrol kualitas, kebutuhan untuk berprestasi, dan komitmen profesional auditor terhadap penghentian dini pada prosedur audit. Penelitian ini berlaku survei mail sebagai metode pengumpulan data dan convienece sampel sebagai metode pengumpulan sampel. Subjek penelitian adalah 106 auditor di Badan Pemeriksa Keuangan Republik Indonesia (BPK RI) Perwakilan Kalimantan Selatan dan Kalimantan Tengah. Bukti empiris menemukan bahwa efek risiko audit terhadap penghentian prematur atas prosedur audit. Namun, tekanan waktu, materialitas, review prosedur dan kontrol kualitas, kebutuhan untuk berprestasi dan komitmen profesional tidak berpengaruh terhadap penghentian prematur atas prosedur audit.

Kata Kunci: Faktor-Faktor; Penghentian dini; Prosedur Audit.

\section{PENDAHULUAN}

Pemerintah bertanggungjawab menyaji-kan laporan terkait pengalokasian dana masyarakat secara transparan dan akuntabel.Upaya untuk menjamin hal ini adalah dengan adanya jasa audit untuk menentukan keandalan pertanggungjawaban keuangan yang disajikan oleh manajemen dalam laporan keuangan.

Pada dasarnya, hasil audit mampu meningkatkan kualitas informasi, namun dalam prakteknya masih terdapat perilaku auditor yang dapat menyebabkan berku-rangnya kualitas audit. Salah satu bentuk perilaku pengurangan kualitas audit adalah penghentian prematur atas prosedur audit (Kholidiah dan Murni (2014). Penghentian prematur atas prosedur audit (Premature Sign Off) didefinisikan sebagai suatu keadaan yang menunjukkan auditor menghentikan satu atau beberapa langkah audit yang diperlukan dalam prosedur audit tanpa menggantikan dengan langkah yang lain (Lestari, 2010).

Praktik penghentian prematur prosedur audit sangat berpengaruh terhadap kualitas laporan audit yang dihasilkan, karena jika salah satu langkah dalam prosedur audit tidak dilakukan, maka 
kemungkinan auditor membuat judgement yang salah akan semakin tinggi. Kesalahan pembuatan judgement yang disebabkan karena auditor tidak melakukan prosedur audit yang mencukupi dapat menyebabkan auditor dituntut secara hukum (Heriningsih, 2002).

Badan Pemeriksa Keuangan (BPK) sebagai salah satu lembaga yang melakukan audit atas pemerintahan dalam praktiknya juga tidak bisa terlepas dari berbagai situasi dan kondisi sulit. Auditor pemerintah sewaktu-waktu dapat terdorong untuk melakukan tindakan penghentian prematur atas prosedur audit. Banyaknya tugas audit yang diemban tidak sebanding dengan jumlah auditor yang dimiliki dan jumlah entitas yang diaudit BPK. BPK wilayah regional Provinsi Kalimantan Selatan harus melakukan audit atas 13 kabupaten/kota dan Provinsi Kalimantan Selatan, sedangkan jumlah auditor yang dimiliki BPK-RI Perwakilan Provinsi Kalimantan Selatan hanya 56 orang. Begitupula untuk wilayah regional Provinsi Kalimantan Selatan, BPK harus melakukan audit atas 14 kabupaten/kota dan jumlah auditor yang dimiliki BPK-RI Perwakilan Provinsi Kalimantan Selatan hanya 50 orang.

Weningtyas et al. (2006) menyatakan bahwa proses penghentian prematur atas prosedur audit tidak hanya disebabkan oleh faktor internal auditor, akan tetapi juga dapat disebabkan dari faktor situasional pada saat melaksanakan proses audit yang merupakan faktor eksternal. Faktor eksternal meliputi tekanan waktu, risiko audit, materialitas, prosedur review dan kontrol kualitas sedangkan faktor internal adalah karakteristik personal.

Terdapat beberapa penelitian yang telah dilakukan berkaitan dengan penghentian prematur atas prosedur audit yaitu penelitian menurut Kholidiah dan Murni (2014), Andani (2014), Qurrahman dan Mirdah (2012), Lestari (2010) dan Weningtyas et al. (2006). Salah satu faktor yang memengaruhi perilaku auditor dalam penghentian prematur atas prosedur audit menurut Kholidiah dan Murni (2014) dan Andani (2014) adalah tekanan waktu. Beberapa faktor lainnya yang juga dapat memengaruhi penghentian prematur atas prosedur audit, diantaranya risiko audit, materialitas, prosedur review dan kontrol kualitas serta need for achievement.

Penelitian ini merupakan pengembangan dari penelitian yang dilakukan oleh Kholidiah dan Murni (2014). Penelitian ini akan menguji kembali pengaruh tekanan waktu, risiko audit, materialitas, prosedur review dan kontrol kualitas serta need for achievement terhadap terjadinya penghentian prematur atas prosedur audit. Perbedaan penelitian ini dengan penelitian Kholidiah dan Murni (2014) terletak pada penambahan variabel independen yaitu komitmen profesional. Alasan penambahan variabel komitmen profesional karena berdasarkan penelitian sebelumnya yang dilakukan oleh Andani (2014), komitmen profesional merupakan bagian dari faktor internal yang diduga dapat memengaruhi penghentian prematur prosedur audit.

Berbeda dengan banyak penelitian sebelumnya terkait faktor yang mempengaruhi penghentian prematur atas pro sedur audit selama ini lebih ditekankan kepada auditor independen dan jarang mengambil subjek pada auditor yang bekerja di Kantor BPK, oleh karena itu peneliti tertarik untuk melakukan penelitian pada auditor yang bekerja di BPK RI Perwakilan Kalimantan Selatan dan Kaliman-tan Tengah. Berdasarkan uraian dalam latar belakang penelitian maka tujuan penelitian ini adalah menguji dan menganalisis pengaruh tekanan waktu, risiko audit, materialitas, prosedur review dan kontrol kualitas, need for ahievement, komitmen profesional berpe-ngaruh terhadap terjadinya penghentian prematur prosedur audit. Alat analisis yang digunakan dalam pengujian hipotesis adalah analisis regresi berganda. 


\section{TINJAUAN LITERATUR DAN PERUMUSAN HIPOTESIS}

\section{TEORI ATRIBUSI}

Teori atribusi memberikan penjelasan proses bagaimana kita menentukan penyebab atau motif perilaku seseorang. Lebih jauh, teori ini diarahkan untuk mengembangkan penjelasan dari cara-cara kita menilai individu secara berbeda, terrgantung pada arti yang kita hubungkan dengan perilaku tertentu (Robbins, 2008). Teori atribusi (Robbins, 2008) menyatakan bahwa ketika mengobservasi perilaku seorang individu, seseorang berupaya untuk menentukan apakah perilaku tersebut disebabkan secara internal atau eksternal. Perilaku yang disebabkan secara internal adalah perilaku yang diyakini dipengaruhi oleh kendali pribadi seorang individu. Perilaku yang disebabkan secara eksternal dianggap sebagai akibat dari sebab-sebab luar yaitu individu tersebut dianggap telah dipaksa berperilaku demikian oleh situasi (Robbins, 2008).

Teori atribusi dapat digunakan sebagai dasar menemukan faktor-faktor penyebab auditor melakukan penghentian prematur atas prosedur audit. Penyebab perilaku penghentian prematur prosedur audit secara internal mengacu pada sesuatu yang ada pada diri auditor seperti kebutuhan untuk berprestasi (need for achievement) dan komitmen profesional. Sedangkan penyebab eksternal mengacu pada lingkungan luar yang memengaruhi perilaku auditor seperti adanya tekanan waktu, risiko audit, materialitas, serta prosedur review dan kontrol kualitas dari tempat auditor bekerja (Evanauli dan Nazaruddin, 2013).

\section{TEKANAN WAKTU DAN PENGHENTIAN PREMATUR ATAS PROSEDUR AUDIT}

Time pressure memiliki dua dimensi yaitu time budget pressure dan time deadline pressure. Time budget pressure adalah keadaan auditor dituntut untuk melakukan efisiensi terhadap anggaran waktu yang telah disusun, atau terdapat pembatasan waktu dalam anggaran yang sangat ketat. Time deadline pressure adalah keadaan dimana auditor dituntut untuk menyelesaikan tugas audit tepat pada waktunya (Kholidiah dan Murni, 2014). Semakin tinggi tekanan waktu yang dirasakan auditor maka perilaku penghentian prematur atas prosedur audit akan semakin tinggi pula. Hipotesis yang diajukan yaitu:

$H_{1}$ : Tekanan waktu berpengaruh positif terhadap penghentian prematur prose-dur audit.

\section{RISIKO AUDIT DAN PENGHENTIAN PREMATUR ATAS PROSEDUR AUDIT}

Menurut Standar Audit Seksi 312 disebutkan:

"Risiko audit adalah risiko yang terjadi dalam hal auditor, tanpa disadari, tidak memodifikasi pendapatnya sebagaimana mestinya, atas suatu laporan keuangan yang mengandung salah saji material."

Ketika auditor menginginkan risiko audit yang rendah berarti auditor ingin semua bahan bukti yang terkumpul dapat mendeteksi adanya salah saji yang material. Agar bahan bukti tersebut dapat digunakan untuk mendeteksi adanya salah saji yang material maka diperlukan jumlah bahan bukti yang lebih banyak dan jumlah prosedur yang lebih banyak pula. Oleh karena itu, auditor tidak akan melakukan penghentian terhadap prosedur audit jika risiko rendah. Hal ini dikarenakan jika auditor melakukan peng-hentian prosedur audit maka kemungkinan terjadinya salah saji akan semakin besar. Berdasarkan argumen di atas maka diduga semakin rendah risiko audit yang diinginkan auditor, semakin rendah keinginan auditor untuk melakukan penghentian prematur atas prosedur audit. Hipotesis yang akan diajukan yaitu:

$\mathrm{H}_{2}$ : Risiko audit berpengaruh positif terhadap penghentian prematur atas prosedur audit. 


\section{MATERIALITAS DAN PENGHENTIAN PREMATUR ATAS PROSEDUR AUDIT}

Materialitas adalah besarnya nilai yang dihilangkan atau salah saji informasi akuntansi, yang dilihat dari keadaan yang melingkupinya, dapat mengakibatkan peruba-han atas atau pengaruh terhadap pertimbangan orang yang meletakkan kepercayaan terhadap informasi tersebut, karena adanya penghilangan atau salah saji itu (Mulyadi, 2011).

Tingginya tingkat materialitas yang ditetapkan oleh auditor menunjukkan semakin tinggi jumlah salah saji yang dapat mempengaruhi keputusan pemakai laporan keuangan. Semakin tinggi tingkat materialitas yang ditentukan oleh auditor maka semakin sedikit bukti audit yang harus dikumpulkan oleh auditor. Hal ini menunjukkan adanya kecenderungan auditor untuk mengabaikan prosedur audit tertentu. Pengabaian ini dilakukan karena auditor beranggapan tingginya nilai salah saji yang dapat diterima tidaklah memerlukan prosedur audit yang lengkap sehingga tidak berpengaruh terhadap opini audit. Pengabaian seperti inilah yang menimbulkan praktik penghentian prematur atas prosedur audit. Semakin tinggi tingkat materialitas yang ditetapkan maka kecen-derungan menghentikan prosedur audit semakin tinggi, sehingga formulasi hipotesis yang diajukan penulis adalah sebagai berikut:

$\mathrm{H}_{3}$ : Materialitas berpengaruh positif terhadap penghentian prematur atas prosedur audit.

\section{PROSEDUR REVIEW DAN KONTROL KUALITAS DAN} PENGHENTIAN PREMATUR ATAS PROSEDUR AUDIT

Weningtyas et al. (2006) mendefinisikan prosedur review sebagai pemeriksaan terhadap kertas kerja yang dilakukan oleh auditor pada level tertentu. Fokus dari prosedur review ini terutama pada hal-hal yang terkait dengan pemberian opini. Berbeda dengan prosedur review yang berfokus pada pemberian opini, kontrol kualitas lebih berfokus pada pelaksanaan prosedur audit sesuai standar auditing.

Kholidiah dan Murni (2014) menemukan adanya pengaruh prosedur review dan kontrol kualitasterhadap penghentian prematur atas prosedur audit. Hasil penelitian ini didukung oleh Qurrahman dan Mirdah (2012), Lestari (2010) dan Weningtyas et al. (2006) yang membuktikan bahwa prosedur review dan kontrol kualitas berpengaruh terhadap penghentian prematur atas prosedur audit. Semakin tinggi prosedur review dan kontrol kualitas, maka semakin rendah kemungkinan auditor melakukan praktik tersebut, sehingga formulasi hipotesis yang diajukan penulis adalah sebagai berikut:

$\mathrm{H}_{4}$ : Prosedur review dan kontrol kualitas

berpengaruh negatif terhadap peng-hentian prematur atas prosedur audit.

\section{NEED FOR ACHIEVEMENT DAN PENGHENTIAN PREMATUR ATAS PROSEDUR AUDIT}

Need for achievement adalah merupakan jenis motivasi. McClelland dalam Prihatsanti (2010) mendefinisikan need for achievement sebagai keinginan seorang individu untuk meningkatkan, atau mempertahankan pada kemampuannya tingkat tinggi dalam kegiatan tertentu. Individu yang memiliki motivasi berprestasi tinggi adalah individu yang mampu mempertahankan standar kinerja tinggi dan mempunyai keinginan untuk menyelesaikan tugas yang sulit (Riyadiningsih, 2002). Oleh karena itu, individu dengan need for achievement tinggi cenderung menghindari tindakan penghentian prematur atas prosedur audit. Mereka mengedepankan mutu dan berusaha menjalankan pekerjaan sesuai standar profesional, dan ini dapat menurunkan terjadinya perilaku penghentian prematur atas prosedur audit. Semakin tinggi need for achievement dalam diri auditor maka akan 
semakin rendah keinginan auditor melakukan penghentian prematur atas prosedur audit. Maka formulasi hipotesis yang diajukan penulis adalah sebagai berikut:

$\mathrm{H}_{5}$ : Need for Achievement berpengaruh negatif terhadap penghentian prematur atas prosedur audit.

Komitmen Profesional dan Penghentian Prematur atas Prosedur Audit

Komitmen profesional didefinisikan sebagai kekuatan relatif dari identifikasi dan keterlibatan individu terhadap suatu profesi. (Aranya dan Ferris, 1984). Penelitian Jeffry dan Weatherholt dalam Silaban (2009) menunjukkan auditor dengan komitmen profesional kuat lebih taat pada aturan dibandingkan dengan auditor yang memiliki komitmen profesional rendah. Qurrahman dan Mirdah (2012) menyebutkan bahwa komitmen professional berpengaruh terhadap peng-hentian prematur prosedur audit. Hasil ini juga didukung oleh penelitian terbaru yang dilakukan oleh Andani (2014) yang membuktikan bahwa komitmen professional berpengaruh terhadap penghentian prematur prosedur audit.

Berdasarkan argumen dan beberapa hasil penelitian sebelumnya. diduga komitmen profesional berpengaruh terhadap penghentian prematur atas prosedur audit. Semakin tinggi komitmen profesional yang dimiliki, maka keinginan auditor untuk melakukan peng-hentian prematur atas prosedur audit akan semakin rendah. Maka formulasi hipotesis yang diajukan penulis adalah sebagai berikut:

$\mathrm{H}_{6}$ : Komitmen profesional berpengaruh negatif terhadap penghentian prematur atas prosedur audit.

\section{METODE PENELITIAN} MODEL PENELITIAN

Berdasarkan perumusan hipotesis, maka model penelitian untuk menguji pengaruh antara tekanan waktu, risiko audit, materialitas, prosedur review dan kontrol kualitas, need for achievement dan komitmen profesional terhadap penghentian prematur atas prosedur audit ditunjukkan di Gambar 1.

Jenis data dalam penelitian ini adalah data primer, yang diperoleh dari pendapat dari pendapat dari auditor BPK-RI Perwakilan Provinsi Kalimantan Selatan dan BPK-RI Perwakilan Provinsi Kalimantan Tengah (106 auditor). Metode pengumpulan data menggunakan mail survey. Tteknik penentuan sampel adalah convenience sampling yaitu memilih sampel dari elemen populasi (orang atau kejadian) yang datanya mudah diperoleh peneliti. Sampel penelitian yang digunakan dalam analisis sebanyak 52 . Hipotesis dalam penelitian ini diuji dengan menggunakan regresi linier berganda.

Pengiriman kuisioner dilakukan pada tanggal 18 November 2014 yang berjumlah 60 eksamplar pada BPK-RI Perwakilan Provinsi Kalimantan Selatan dan 50 eksemplar pada BPK RI Perwakilan Provinsi Kalimantan Tengah. Kuisioner kembali pada tanggal 24 Desember 2014 berjumlah 40 eksamplar pada BPK-RI Perwakilan Provinsi Kalimantan Selatan dan 25 eksemplar pada BPK RI Perwakilan Provinsi Kalimantan Tengah.

Jumlah kuisioner yang kembali adalah berjumlah 65 eksamplar dengan tingkat pengembalian 59,09\%. Tingkat pengembalian yang demikian tersebut dikarenakan waktu penelitian yang bertepatan dengan waktu para auditor pemerintah melakukan pemeriksaan sehingga kebanyakan dari mereka berada di luar kota pada saat kuisioner dibagikan. Tabel 1 menyajikan tingkat pengembalian kuisioner. Tabel 2 menunjukkan deskripsi profil responden dalam penelitian ini yang meliputi jenis kelamin, pendidikan terakhir, jabatan, usia serta lama pengalaman kerja. 


\section{DEFINISI OPERASIONAL DAN PENGUKURAN VARIABEL}

Variabel dependen dalam penelitian ini adalah penghentian prematur atas prosedur audit. Variabel independen adalah tekanan waktu, risiko audit, materialitas, prosedur review dan kontrol kualitas, need for achievement, dan komitmen profesional. Definisi operasional dan pengukuran dari masingmasing variabel akan dijelaskan berikut ini:

\section{Tekanan Waktu}

Tekanan Waktu berkaitan dengan kondisi tekanan yang dirasakan auditor untuk menyelesaikan pekerjaan sesuai waktu yang ditentukan. Instrumen yang digunakan untuk mengukur variabel ini diadopsi dari Lestari (2010). Ada 5 item yang digunakan untuk mengukur tekanan waktu dengan skala 5 (lima) poin. Format respon menunjukkan mulai dari sangat tidak setuju (skor 1) hingga sangat setuju (skor 5). Skor yang tinggi menunjukkan tingginya tekanan waktu yang dirasakan oleh responden dan sebaliknya skor rendah menunjukkan rendahnya tekanan waktu yang dirasakan responden.

\section{Risiko Audit}

Risiko audit berkaitan dengan risiko yang berani ditanggung auditor dalam hal tanpa disadari tidak memodifikasi pendapatnya sebagaimana mestinya sehingga mengandung salah saji material.

Instrumen yang digunakan untuk mengukur variabel ini diadopsi dari Lestari (2010). Ada 3 item yang digunakan untuk mengukur risiko audit dengan skala 5 (lima) poin. Format respon menunjukkan mulai dari sangat tidak setuju (skor 1) hingga sangat setuju (skor 5). Skor yang tinggi menunjukkan tingginya risiko audit yang berani ditanggung responden dan sebaliknya skor rendah menunjukkan rendahnya risiko audit yang berani ditanggung responden.

\section{Materialitas}

Materialitas berkaitan dengan besarnya nilai salah saji yang dihilangkan yang dapat berpengaruh terhadap pertimbangan orang untuk mempercayai informasi laporan keuangan. Instrumen yang digunakan untuk mengukur variabel ini diadopsi dari Lestari (2010). Ada 3 item yang digunakan untuk mengukur materialitas dengan skala 5 (lima) poin. Format respon menunjukkan mulai dari sangat tidak setuju (skor 1) hingga sangat setuju (skor 5). Skor yang tinggi menunjukkan tingginya nilai salah saji yang dihilangkan responden yang dapat berpengaruh terhadap pertimbangan orang untuk mempercayai informasi laporan keuangan, dan sebaliknya skor rendah menunjukkan rendahnya nilai salah saji yang dihilangkan responden yang dapat berpengaruh terhadap pertimbangan orang untuk mempercayai informasi laporan keuangan.

\section{Prosedur Review Dan Kontrol Kualitas \\ Prosedur review dan kontrol kualitas terkait} dengan pemeriksaan dan kontrol atas prosedur review dan kontrol kualitas pelaksanaan prosedur audit dan kertas kerja di BPK-RI Perwakilan Provinsi Kalimantan Selatan dan Tengah dalam mendeteksi tindakan penghentian prematur atas prosedur audit. Instrumen yang digunakan untuk mengukur variabel ini diadopsi dari Lestari (2010). Ada 5 item yang digunakan untuk mengukur prosedur review dan kontrol kualitas dengan skala 5 (lima) poin. Format respon menunjukkan mulai dari sangat tidak setuju (skor 1) hingga sangat setuju (skor 5). Skor yang tinggi menunjukkan tingginya prosedur review dan kontrol kualitas yang dimiliki oleh BPK, dan sebaliknya skor rendah menunjukkan menunjukkan rendahnya prosedur review dan kontrol kualitas yang dimiliki oleh BPK. 


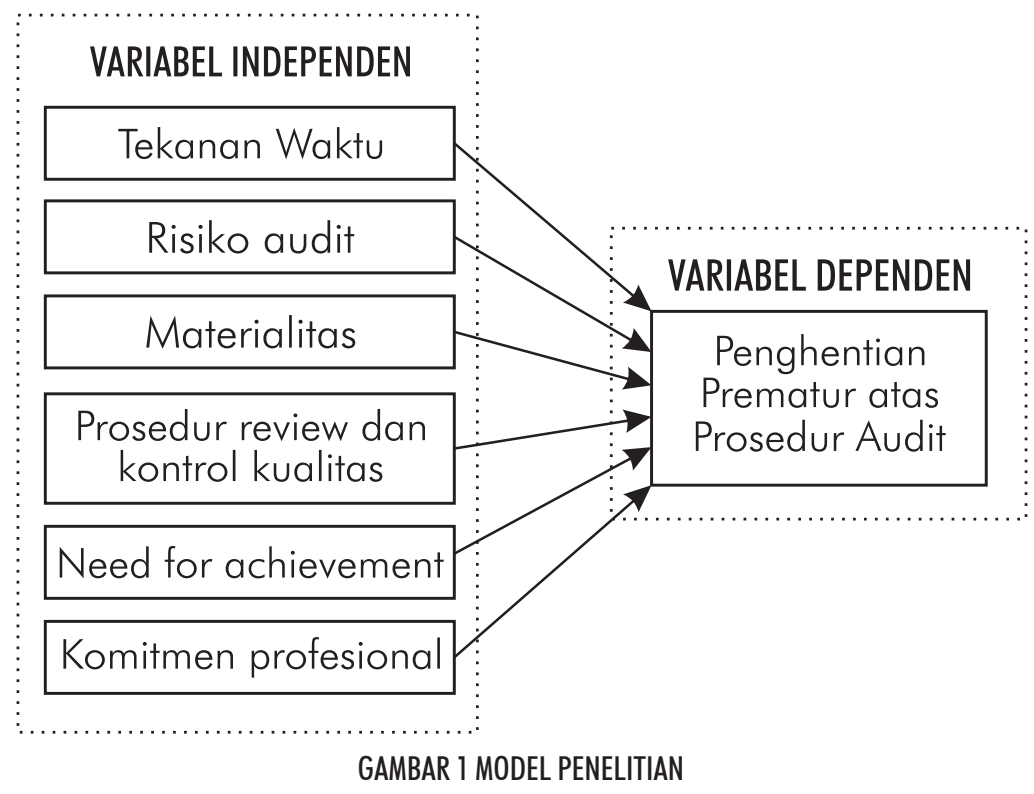

\section{Need for Achievement}

Need for achievement terkait dengan keinginan individu dalam meningkatkan atau mempertahankan kinerja yang tinggi. Instrumen yang digunakan untuk mengukur variabel ini diadopsi dari Prihatsanti (2010). Ada 5 item yang digunakan untuk mengukur need for achievement dengan skala 5 (lima) poin. Format respon menunjukkan mulai dari sangat tidak setuju (skor 1) hingga sangat setuju (skor 5). Skor yang tinggi menunjukkan tingginya need for achievement yang dimiliki responden dan sebaliknya skor rendah menunjukkan rendahnya need for achievement yang dimiliki responden.

\section{Komitmen profesional}

Komitmen profesional terkait dengan kekuatan atas keterlibatan individu terhadap profesi yang digelutinya dengan berpegang teguh pada nilai-nilai profesionalisme. Instrumen yang digunakan untuk mengukur variabel ini diadopsi dari Silaban (2009). Ada 18 item yang digunakan untuk mengukur komitmen profesional dengan skala 5 (lima) poin. Format respon menunjukkan mulai dari sangat tidak setuju (skor 1) hingga sangat setuju (skor 5). Skor yang tinggi menunjukkan tingginya komitmen profesional yang dimiliki responden.

Penghentian prematur atas prosedur audit

Penghentian prematur atas prosedur audit merupakan keadaan dimana auditor melakukan tindakan penghentian satu atau beberapa prosedur audit tanpa menggantinya dengan prosedur lain. Instrumen yang digunakan untuk mengukur variabel ini diadopsi dari Lestari (2010). Ada 10 item yang digunakan untuk mengukur penghentian prematur atas prosedur audit dengan skala 5 (lima) poin. Format respon menunjukkan mulai dari sangat tidak setuju (skor 1) hingga sangat setuju (skor 5). Skor yang tinggi menunjukkan tingginya tindakan penghentian prematur atas prosedur audit yang dilakukan responden dan sebaliknya skor rendah menunjukkan rendahnya tindakan penghentian prematur atas prosedur audit yang dilakukan responden.

\section{HASIL DAN PEMBAHASAN}

Proses analisis data yang dilakukan meliputi 
proses pemilihan data, karakteristik responden, statistik deskriptif, pengujian asumsi-asumsi klasik, uji kelayakan model, dan pengujian hipotesis. Hasil pengujian hipotesis dalam penelitian ini dapat dilihat pada tabel 3 hasil uji hipotesis. Hasil penelitian menunjukkan bahwa tekanan waktu tidak berpengaruh positif terhadap perilaku auditor dalam penghentian prematur atas prosedur audit. Hasil analisis regresi menunjukan nilai $t$ hitung sebesar -2,434 dengan tingkat signifikansi 0,019 ( $p$ > $0,05)$. Walaupun tingkat signifikansinya diterima namun arah koefisien menunjukkan arah yang berlawanan dengan hipotesis, oleh karena itu hipotesis ditolak. Bukti empiris hasil penelitian ini menunjukkan bahwa semakin tinggi tekanan waktu berarti maka semakin rendah kecenderungan auditor melakukan tindakan pengentian prematur atas prosedur audit yang dilakukan.

Hasil penelitian ini menolak hipotesis yang diajukan, hal ini diduga auditor telah terbiasa bekerja dalam tekanan waktu. Meskipun anggaran waktu yang diberikan sangat ketat dan auditor sering melakukan lembur, namun auditor masih menyediakan waktu cadangan untuk menyelesaikan pekerjaan audit sehingga auditor cenderung mampu tetap melaksanakan seluruh prosedur audit.

TABEL 3. HASIL UJ HIPOTESIS

\begin{tabular}{lll}
\hline Variabel & $t$ & Sig. \\
\hline TW & $-2,434$ &, 019 \\
RA & 3,979 &, 000 \\
M & 1,190 &, 240 \\
PR &,- 591 &, 558 \\
NA & 1,796 &, 079 \\
KP & $-1,297$ &, 201 \\
\hline
\end{tabular}

Hasil penelitian berikutnya menunjukkan bahwa risiko audit berpengaruh positif terhadap perilaku auditor dalam penghentian prematur atas prosedur audit. Hasil analisis didukung dengan hasil analisis
TABEL I. TINGKAT PENGEMBALIAN KUISIONER

\begin{tabular}{llllll}
\hline Lokasi & $\begin{array}{l}\text { Kuisioner } \\
\text { disebar }\end{array}$ & $\begin{array}{l}\text { Kuisioner } \\
\text { Kembali }\end{array}$ & $\begin{array}{l}\text { Respon } \\
\text { Rate (\%) }\end{array}$ & $\begin{array}{l}\text { Kuisioner } \\
\text { yang tidak } \\
\text { dapat diolah }\end{array}$ & $\begin{array}{l}\text { Kuisioner } \\
\text { yang dapat } \\
\text { diolah }\end{array}$ \\
\hline $\begin{array}{l}\text { BPK-Rl Perwakilan } \\
\text { Kalimantan Selatan }\end{array}$ & 60 & 40 & 66,67 & 7 & 33 \\
$\begin{array}{l}\text { BPK-Rl Perwakilan } \\
\text { Kalimantan Tengah }\end{array}$ & 50 & 25 & 50 & 6 & 19 \\
Total & 110 & 65 & 59,09 & 13 & 52 \\
\hline
\end{tabular}

TABEL 2. DESKRIPSI PROFIL RESPONDEN

\begin{tabular}{|c|c|c|c|}
\hline No & Keterangan & Total & Persentase \\
\hline \multirow[t]{4}{*}{1} & Jenis Kelamin & & \\
\hline & Pria & 29 & $55,8 \%$ \\
\hline & Wanita & 23 & $44,2 \%$ \\
\hline & Tidak dijawab & 0 & 0 \\
\hline \multirow[t]{9}{*}{2} & Pendidikan & & \\
\hline & S3 & 0 & 0 \\
\hline & S2 & 10 & $19,23 \%$ \\
\hline & $\mathrm{Sl}$ & 39 & $75,00 \%$ \\
\hline & D4 & 2 & $3,85 \%$ \\
\hline & D3 & 1 & $1,92 \%$ \\
\hline & PPAk & 0 & 0 \\
\hline & Lainnya... & 0 & 0 \\
\hline & Tidak dijawab & 0 & 0 \\
\hline \multirow[t]{7}{*}{3} & Jabatan & & \\
\hline & Pemeriksa Pertama & 28 & $53,85 \%$ \\
\hline & Pemeriksa Muda & 18 & $34,61 \%$ \\
\hline & Pemeriksa Madya & 0 & 0 \\
\hline & Pemeriksa Utama & 0 & 0 \\
\hline & Lainnya... & 0 & 0 \\
\hline & Tidak dijawab & 6 & $11,54 \%$ \\
\hline \multirow[t]{6}{*}{4} & Usia & & \\
\hline & $<25$ tahun & 2 & $3,85 \%$ \\
\hline & 25-30 tahun & 15 & $28,85 \%$ \\
\hline & $31-35$ tahun & 16 & $30,77 \%$ \\
\hline & $>35$ tahun & 14 & $26,92 \%$ \\
\hline & Tidak dijawab & 5 & $9,61 \%$ \\
\hline \multirow[t]{6}{*}{5} & $\begin{array}{l}\text { Pengalaman sebagai } \\
\text { Auditor }\end{array}$ & & \\
\hline & $>15$ tahun & 5 & $9,61 \%$ \\
\hline & 11-15 tahun & 7 & $13,47 \%$ \\
\hline & 6-10 tahun & 25 & $48,08 \%$ \\
\hline & 1-5 tahun & 14 & $26,92 \%$ \\
\hline & Tidak dijawab & 1 & $1,92 \%$ \\
\hline
\end{tabular}


regresi yang menunjukkan bahwa nilai thitung sebesar 3,979 dengan tingkat signifikansi 0,000 ( $p<$ 0,05). Bukti empiris ini menunjukkan bahwa ketika auditor menginginkan risiko yang rendah berarti auditor ingin semua bahan bukti yang terkumpul dapat mendeteksi adanya salah saji yang material. Agar bahan bukti tersebut dapat mendeteksi adanya salah saji yang material maka diperlukan jumlah bahan bukti yang lebih banyak dan jumlah prosedur yang lebih banyak pula. Hal ini membuat auditor menghindari perilaku penghentian prematur atas prosedur audit. Sebaliknya ketika auditor menginginkan risiko yang tinggi berarti diperlukan jumlah bahan bukti yang lebih sedikit dan jumlah prosedur yang sedikit pula. Hal ini membuat auditor melakukan penghentian prematur atas prosedur audit.

Hasil pengujian menunjukkan bahwa materialitas tidak berpengaruh positif terhadap perilaku auditor dalam penghentian prematur atas prosedur audit. Hal ini didukung dengan hasil analisis regresi diperoleh nilai $t$ hitung sebesar 1,190 dengan tingkat signifikansi 0,240 ( $p>0,05)$. Hasil penelitian ini menunjukkan bahwa materialitas tidak menjadi faktor yang dapat memengaruhi auditor dalam melakukan penghentian prematur atas prosedur audit. Hal ini diduga karena materialitas melekat pada laporan keuangan sehingga hal ini tidak akan mempengaruhi tahapan audit yang dilakukan oleh auditor. Dalam audit atas laporan keuangan, auditor tidak dapat memberikan jaminan bagi pemakai laporan keuangan bahwa laporan keuangan auditan adalah akurat. Oleh karena itu auditor hanya dapat memberikan keyakinan melalui tingkat materialitas yang ditetapkan. Selain itu, perancangan prosedur pemeriksaan dan pemilihan sampel telah mempertimbangkan materialitas, sehingga prosedur audit yang dirancang telah applicable dengan sampel yang dipilih.
Hasil penelitian menunjukkan prosedur review dan kontrol kualitas tidak berpengaruh negatif terhadap perilaku auditor dalam penghentian prematur atas prosedur audit. Hal ini didukung dengan hasil analisis regresi diperoleh nilai $t$ hitung sebesar -0,591 dengan tingkat signifikansi 0,558 ( $p$ $>0,05)$. Hasil penelitian menunjukkan bahwa prosedur review dan kontrol kualitas yang dijadikan kontrol atas pelaksanaan tugas yang dibebankan bukan menjadi faktor penghalang bagi auditor untuk melakukan penghentian prematur atas prosedur audit. Hal ini disebabkan karena ketika auditor melakukan praktik penghentian prematur atas prosedur audit, auditor tetap merasa mampu menghasilkan hasil audit yang berkualitas, sehingga auditor mungkin saja tetap melakukannya meskipun telah diciptakan prosedur review dan kontrol kualitas terhadap pekerjaannya.

Bukti empiris dalam penelitian ini menunjukkan need for achievement tidak berpengaruh negatif terhadap perilaku auditor dalam penghentian prematur atas prosedur audit. Hasil analisis regresi menunjukkan nilai $t$ hitung sebesar 1,796 dengan tingkat signifikansi 0,079 ( $p>$ $0,05)$. Penolakan hipotesis ini menunjukkan bahwa need for achievement yang merupakan pengaruh internal dalam diri auditor tidak memberi pengaruh terhadap perilaku auditor dalam penghentian prematur atas prosedur audit. Hal ini diduga perilaku penghentian prematur atas prosedur audit yang dilakukan oleh auditor lebih dipengaruhi oleh faktor lingkungan pekerjaan seperti adanya tekanan waktu ataupun adanya produk hukum yang ketat mengikat auditor..

Hasil penelitian juga menunjukkan bahwa komitmen profesional tidak berpengaruh negatif terhadap perilaku auditor dalam penghentian prematur atas prosedur audit. Hal ini didukung hasil analisis regresi yang menunjukkan nilai $t$ hitung sebesar -1,297 dengan tingkat signifikansi 
0,201 ( $p>0,05)$. Penolakan hipotesis dalam penelitian ini diduga karena sedikitnya auditor dengan jabatan fungsional tinggi yang menjadi responden penelitian ini. Responden mayoritas masih pemeriksa pertama. Berdasarkan Peraturan BPK No. 4 tahun 2010 tentang jabatan fungsional pemeriksa, pemeriksa pertama memiliki peran sebagai anggota tim yunior, anggota tim senior dan ketua tim yunior sehingga diduga dengan peran yang masih tergolong di level rendah tersebut auditor belum memiliki komitmen profesional yang tinggi.

\section{SIMPULAN}

Berdasarkan hasil analisis regresi linier berganda dengan pengujian hipotesis dapat disimpulkan bahwa tekanan waktu dan materialitas tidak berpengaruh positif terhadap penghentian prematur atas prosedur audit. Risiko audit berpengaruh positif terhadap penghentian prematur atas prosedur audit. Prosedur review dan kontrol kualitas, need for achievement, komitmen profesional tidak berpengaruh negatif terhadap penghentian prematur atas prosedur audit.

Beberapa implikasi yang diharapkan pada penelitian ini adalah: BPK diharapkan dapat terus mengupayakan perbaikan pada beberapa faktor eksternal yang dapat mendorong auditor melakukan tindakan penghentian prematur atas prosedur audit, seperti melakukan evaluasi atas time budget dan time deadline dengan mengadministrasikan atau membuat skedul kerja dengan realistis, mengkomunikasikan risiko audit dan materialitas dengan jelas kepada auditor, memberikan pemahaman akan pentingnya risiko audit dan materialitas demi menghasilkan audit yang berkualitas. Selain itu BPK sebaiknya serius menjalankan dan memperketat prosedur review dan kontrol kualitas agar tindakan penghentian prematur atas prosedur audit tidak terjadi. Selain itu, BPK diharapkan terus mampu mengoptimalkan diklat-diklat demi meningkatkan motivasi dan profesionalisme auditor agar mindset untuk tetap bertanggungjawab, berkomitmen dan patuh terhadap peraturan terus terjaga.

Penelitian ini tidak terlepas dari keterbatasan dan kelemahan. Beberapa keterbatasan ini tersebut antara lain: penelitian ini menggunakan objek auditor BPK sedangkan penelitian sebelumnya lebih banyak mengambil objek pada auditor KAP, sehingga diduga terjadi anomali penelitian karena penelitian ini dilakukan pada auditor BPK. Selain itu penelitian ini dilakukan di bulan November sampai awal Januari yang merupakan masa sibuk kerja auditor dalam mengaudit sehingga peneliti mengalami kesulitan mendapatkan data dan responden tidak memahami kuisioner dengan baik. Keterbatasan lain yakni instrumen pengukuran variabel penelitian ini semuanya menggunakan instrumen dari penelitian sebelumnya yang disesuaikan dengan bahasa yang berbeda dari aslinya, sehingga diduga ada kelemahan dalam penerjemahan instrumen yang menyebabkan terjadinya perubahan makna yang sebenarnya ingin dicapai.

Penelitian selanjutnya diharapkan lebih memperhatikan dugaan terjadinya anomaly penelitian dari sektor swasta ke sektor public dengan mempertimbangkan secara lebih mendalam terkait perbedaan karakteristik objek dan kuisioner yang dipakai. Penelitian berikutnya sebaiknya mempertimbangka nuntuk memperluas jangkauan penelitian, tidak hanya terfokus pada auditor di BPK-RI PerwakilanProvinsi Kalimantan Selatan dan Kalimantan Tengah. Penelitian selanjutnya hendaknya melakukan pengumpulan data dengan teknik wawancara sehingga lebih dapat dipastikan data yang didapatkan lebih akurat. Kuisioner sebaiknya diberi ilustrasi dan gambaran umum atas variabel yang ingin diteliti sehingga dapat 
menyamakan persepsi responden dengan peneliti mengenai penelitian yang diselenggarakan.

Penelitian selanjutnya diharapkan dapat menguji variabel karakteristik internal lainnya yang kemungkinan berpengaruh terhadap penghentian premature atas prosedur audit seperti komitmen organisasi, self esteem, dan motivasi.

\section{DAFTAR PUSTAKA}

Almar'atus, A. 2013. Pengaruh Time Pressure, Audit Risk, Need For Achievement, Quality Control dan Review Procedures Terhadap Premature Sign-Off. Skripsi, Universitas Airlangga.

Andani, N. M. S. dan I. M. Mertha. 2014. Pengaruh Time Pressure, Audit Risk, Professional Commitment dan Locus of Control pada Penghentian Prematur Prosedur Audit. E-jurnal Akuntansi Universitas Udayana, 6 (2), 185-196

Aranya, N., dan K. R. Ferris. 1984. A Reexamination of Accountants Organi-zation-Profesional Conflict. The Accounting Review, 59 (1), 1-15.

Arens A. A.. 2011. Auditing and Assurance Services An Integrated Approach-An Indonesia Adaptation; Jasa Audit dan Assurance Pendekatan Terpadu (Adaptasi Indonesia). Amir Abadi Jusuf. (Terjemahan). Buku 1. Jakarta: Salemba Empat.

Arikunto, Suharsimi. 2014. Prosedur Penelitian, Suatu Pendekatan Praktik. Jakarta: Rineka Cipta.

Badan Pemeriksa Keuangan, 2007. Peraturan Badan Pemeriksa Keuangan Republik Indonesia No. 01 Tahun 2007 tentang Standar Pemeriksaan Keuangan Negara.

Badan Pemeriksa Keuangan, 2010. Peraturan BPK RI No. 4 tahun 2010 tentang Jabatan fungsional pemeriksa pada Badan Pemeriksa Keuangan.

Badan Pemeriksa Keuangan, 2014. Keputusan BPK-RI Nomor 3/K/IXIII.2/7/2014 tentang Organisasi dan Tata Kerja Pelaksana Badan Pemeriksa Keuangan.

Evanauli, R. P. Dan I. Nazaruddin. 2013. Penerimaan Auditor Atas Dysfunctional Audit Behavior: Sebuah Pendekatan Karakteristik Personal Auditor. Jurnal Akuntansi dan Investasi, 14 (2), 176-190.

Ghozali, I. 2011, Aplikasi Analisis Multivariate dengan Program IBM SPSS19, Edisi Kelima. Semarang: Badan Penerbit Universitas Dipenogoro.

Heriningsih, S. 2002. Penghentian Prematur atas Prosedur Audit : Studi Empiris pada Kantor Akuntan Publik. Wahana, 2 (8), 111-123.

Kholidiah dan S. A. Murni. 2014. Analisis Faktor-faktor yang Berpengaruh terhadap Penghentian Prematur (Prematur Sign-off) atas Prosedur Audit (Studi Kasus pada Kantor Akuntan Publik di Jawa Timur). Paper Dipresentasikan di Simposium Nasional Akuntansi XVII, Mataram.

Lestari, A. P. 2010. Faktor-faktor yang Mempengaruhi Perilaku Auditor dalam Penghentian Prematur atas Prosedur Audit. Skripsi.Universitas Dipenogoro Semarang.

Mulyadi. 2012. Auditing, Edisi 6. Salemba Empat. Jakarta.

Prihatsanti, U. 2010. Hubungan Kepuasan Kerja Dan Need For Achievement Dengan Kecenderungan Resistance To Change Pada Dosen Undip Semarang. Jurnal Psikologi Undip, 8 (2) 45-57.
Qurrahman, T. dan A. Mirdah. . 2012. Pengaruh Time Pressure, Risiko Audit.Materialitas, Prosedur Review dan Kontrol Kualitas, Locus Of Contro/ serta Komitmen Profesional Terhadap Penghentian Prematur Prosedur Audit : Studi Empiris pada KAP di Palembang. e-Jurnal Binar Akuntansi, 1 (1) 35-49.

Riyadiningsih. 2002. Hubungan Variabel Kepribadian dan Motivasional dengan Tingkat Kinerja Individual. Jurnal Bisnis dan Ekonomi.

Robbins, P. S. 2008. Perilaku Organisasi. Edisi Duabelas. Jakarta: Penerbit Salemba Empat.

Silaban, A. 2009. Perilaku Disfungsional Auditor Dalam Melaksanakan Program Audit : Studi Empiris di Kantor Akuntan Publik. Disertasi, Universitas Dipone-goro

Surodilogo, L. B.. 2010. Analisis Pengaruh Lingkungan Kerja dan Motivasi Kerja terhadap Kepuasan Kerja Karyawan PT Sumber Sehat Semarang. Skripsi, Universitas Diponegoro.

Weningtyas, Suryanita, Doddy Setiawan, dan Hanung Triatmoko, 2006. Penghentian Prematur Atas Prosedur Audit. Paper Dipresentasikan di Simposium Nasional Akuntansi IX, Padang. 